\title{
Has the sovereign debt crisis changed the cyclicality of Portuguese remittances?
}

\author{
Leonida Correia (iD) and Patrícia Martins (iD)
}

Centre for Transdisciplinary Development Studies (CETRAD), Department of Economics, Sociology and Management (DESG), University of Trás-os-Montes and Alto Douro (UTAD), Vila Real, Portugal

\begin{abstract}
This paper explores the cyclicality of remittances into Portugal from 1996 to 2015. Using bilateral correlations and econometric model regression approaches, we investigate if remittances are countercyclical or procyclical with Portuguese, French and Swiss outputs (France and Switzerland being the two main remitting countries). We also examine the ability of remittances to smooth macroeconomic shocks, and compare their role with other external financial sources. The empirical results suggest that the sovereign debt crisis has changed the cyclicality of remittances from procyclical in relation to Portuguese GDP in the years before the crisis to countercyclical during the crisis period. This conclusion is valid regardless of the economic situation of home and host countries and is robust to the use of different statistical information to measure the business cycle of Portugal (GDP, private consumption, or unemployment rate). Thus, we conclude that remittances received by Portuguese households played an economic stabilization role in the crisis years.
\end{abstract}

\section{ARTICLE HISTORY}

Received 9 May 2017

Accepted 12 January 2018

\section{KEYWORDS}

Migration; remittances; cyclicality; sovereign debt crisis; Portugal

\section{JEL CLASSIFICATION}

E32; F22; F24

\section{Introduction}

The intensification of global migration flows since the 1970s stimulated the payment of international remittances, which became an important source of external financing, particularly for developing countries (World Bank 2014). International estimates suggest that in 2015 more than 251 million people lived and worked outside their country of birth. Workers' remittances to their families in their home countries exceeded $\$ 601$ billion in that year, and most of these remittances were sent to developing countries (World Bank Group 2016). ${ }^{1}$

In the case of Portugal, empirical evidence shows that, although migratory movements have been important for a long time, they have changed significantly in terms of emigration and immigration. Until the 1990s, Portugal could be characterized as a country of emigration. The flows of emigrants and immigrants then became relatively balanced, and this lasted until the end of 2000s, when emigration began to increase and immigration decreased substantially. Nowadays, Portugal is again a country of emigration. 
The increase in Portuguese emigration was particularly strong after the global financial crisis that spread to the European Union (EU) during the autumn of 2008. Of the EU Member States, Portugal and the other southern European countries were the most affected by the Great Recession. In fact, the economic and sovereign debt crises had extensive negative economic and social consequences in Portugal, where many jobs were lost, with thousands of people becoming unemployed, with some being thrown into poverty. The Economic and Financial Assistance Programme (EFAP) agreed in 2011 between the Portuguese authorities, the EU and the International Monetary Fund (IMF), required Portugal to implement austerity measures to receive the bailout package of $€ 78$ billion; these measures deepened the recession and increased the unemployment rate (Correia 2016).

The crisis and the austerity measures contributed to an intensification of Portuguese emigration, which is one of the most important recent transformations in the Portuguese economy. Data from the United Nations (2015) show that in 2015 there were 2,306,321 Portuguese-born people living abroad (equivalent to $22 \%$ of the population); this was 207,424 more individuals than in 2010 (a growth of about 10\%). Portugal was included in the top 10 countries for emigration in the group of high-income OECD countries (World Bank Group 2016). In the context of the EU, Portugal occupied the second position in 2015, after Malta, in terms of the rate of emigration, and the first of countries with more than a million inhabitants (Pires et al. 2016). As a result, remittances as a share of GDP increased after the beginning of this decade, reversing a situation of decline that had lasted since the 1980s.

Remittances play a central role in the socio-economic effects of migration flows. There is a substantial literature on the determinants of remittances and their impact over the long term, although the cyclical properties of remittances (i.e. how their fluctuations are related to the business cycle) is largely unaddressed. Moreover, the findings from earlier empirical studies are ambivalent, varying across countries and over time, which leaves this area open for further research.

This study contributes to the debate surrounding the cyclical behaviour of remittances in several ways. First, we conduct an analysis of the relationship between the cycle of remittances and the aggregated fluctuations at country-level for Portugal, using time series data for 1996-2015. Most empirical work focuses on this question for several countries (panel data), therefore assuming the estimated effects to be the same for all countries in the sample. Nevertheless, the specificities of each country, in terms of the dynamics of emigration flows and economic conditions, mean that the impact of remittances may vary substantially between countries, and this underlines the need for individual country studies. Furthermore, traditional studies of remittance flows have mainly focused on developing countries, and have paid much less attention to developed countries. Specifically, no published studies, as far we know, have provided information on the cyclical pattern of workers' remittances to Portugal, even though Portugal recently re-emerged as an important receiver of remittances.

Second, we carry out an empirical investigation of the smoothing hypothesis, asking whether remittances tend to move in the opposite direction to the Portuguese business cycle, thus smoothing the impact of macroeconomic fluctuations, and whether they have provided a cushion against economic shocks such as the recent recession. As mentioned above, the economic and the sovereign debt crises contributed to the 
intensification of Portuguese emigration and to the increase in inward remittances, which suggests that remittances behaved in a countercyclical way in this period.

Third, in the empirical literature remittances are generally considered to be an important source of external funding. Thus, another objective is to compare the cyclicality of remittances with that of other external financial sources. To do this, we have chosen two items of the balance of payments that have a special role in offsetting the Portuguese external deficit: receipts from tourism and travel, and capital transfers. This analysis is important because the EFAP was intended to reduce the external Portuguese debt, correcting the net borrowing situation that had been repeated in Portugal for many years.

The remainder of the paper is structured as follows. Section 2 reviews the literature. Section 3 presents some facts about the development of Portuguese remittances, and includes a comparison with other relevant socio-economic variables. Section 4 contains the empirical analysis, which involves a description of the data and methodology used, as well a discussion of the correlations and econometric results. Section 5 concludes.

\section{Literature review}

The importance of remittances for economic development is widely recognized in theory and in economic history. Consequently, there has been a growing interest within the research community in the influence of remittances on enhancing economic growth and well-being as well as on reducing poverty in home countries.

At the macroeconomic level, a substantial amount of literature has focused on the determinants of remittances and on their long-run economic consequences, mainly for groups of poor or developing countries. However, given the controversy over the effects on sources of growth, these studies have provided mixed results about the relationship between remittances and economic growth. Specifically, alongside some evidence supporting the argument that remittances contribute to the accumulation of production factors such as physical and human capital, some studies have reported the so-called 'Dutch disease effects', or negative effects on production through the real appreciation of domestic currencies and the loss of international competitiveness (Acosta, Lartey, and Mandelman 2009).

In this sense, using an enlarged panel model of 113 countries, the influential paper of Chami, Fullenkamp, and Jahjah (2005) suggests a negative and significant relationship between remittances and GDP growth, with this result being explained by moral hazard or adverse incentive problems. A similar negative relationship was found by Barajas et al. (2009) and Le (2009). Contradicting this pessimistic view, other studies, such as those of Acosta et al. (2008), Giuliano and Ruiz-Arranz (2009) and Ziesemer (2012), concluded that remittances had a positive impact on economic growth, whereas Senbeta (2013) found an insignificant effect. According to Ziesemer (2012), studies for small groups of countries have more often generated a positive result than works using large samples of countries, which may indicate some heterogeneity within large samples.

A more recent line of research concerns the cyclical properties of remittances that is, how their cyclical fluctuations are related to business cycles. The theoretical foundation of the debate about the cyclicality of remittances is provided by the literature examining the motives to remit. At the microeconomic level, Lucas and Stark (1985) were the first to produce a model analysing the factors that affect the 
behaviour of migrants. Following this pioneering contribution, the literature has suggested several reasons for remitting, with altruism and self-interest being the fundamental motives driving the behaviour of remitters. Emigrants acting altruistically send remittances to help family members in their country of origin, without having a pecuniary or other material interest. In contrast, emigrants acting from selfinterest remit with the purpose of investing or ensuring an inheritance from the family assets.

When the altruistic motive prevails, remittances are countercyclical. Migrants remit more during economic downturns in their home country, to compensate their families for the decline in household income due to potential wage cuts or unemployment. In this case, remittances may stabilize the impact of macroeconomic fluctuations in the recipient country, temporarily smoothing consumption and investment (World Bank 2006). Under this smoothing hypothesis, remittances provide recipient countries with a cushion against economic shocks, assuming the role often assigned to capital inflows but rarely played by them in practice.

On the other hand, remittance inflows would be expected to decrease during an economic crisis, and increase in the periods of prosperity in the migrant home country, when the investment (or portfolio diversification) motive is dominant. In this situation, remittances tend to display procyclical behaviour similar to that expected for capital inflows, and the receiving countries cannot use the remittances to offset negative cyclical fluctuations in GDP. Procyclical remittances may even be a destabilizing force, exacerbating fluctuations in output or current account balances and having a damaging macroeconomic impact (Sayan 2006).

It is not easy to identify which motive is stronger, because of problems with data availability and because different migrants will have different reasons to remit, and these may change over time (Artal-Tur et al. 2014). Hence, the results of empirical studies remain inconclusive, with different results depending on the sample of countries, the period of analysis and the measure of remittances used.

Supporting the first view that remittances are driven mainly by altruism, several studies using panel data, such as Sayan (2006) for a group of 12 developing countries, and Frankel (2011) for a larger bilateral data set of developed and developing countries, find evidence of countercyclical remittances. Their general conclusion is that the countercyclicality of remittances may enable remittances to have a significant impact on smoothing macroeconomic fluctuations in recipient countries and buffering macroeconomic shocks. A related strand of literature investigates the impact of remittances on output growth volatility. Using data for 70 countries, of which 16 were advanced economies and 54 were developing countries, Chami, Hakura, and Montiel (2009) concluded that remittances decrease the output growth volatility of home countries, which also supports the view that remittance flows have a stabilizing influence on output.

The other view that emigrants remit for investment purposes, is supported by studies across countries that report a positive relationship between the cycle of remittances and the receiving country's business cycle. Lueth and Ruiz-Arranz (2006) based on the estimation of a gravity model for 11 developing countries in Asia and Europe, Giuliano and Ruiz-Arranz (2009) for a sample of approximately 100 developing countries, and Neagu and Schiff (2009) for 116 developing countries, found that remittances are procyclical. 
The outcome of countercyclicality or procyclicality obtained from panel data analysis is not proved at country-specific level, implying that the cyclical behaviour found for a whole group of countries may not apply to the individual level (Sayan 2006), and that time-series analysis for particular countries could provide useful information (Giuliano and Ruiz-Arranz 2009).

The relationship between remittances and the business cycle of sending countries also matters. The level of wages and unemployment depends on the economic conditions in the host country, and these have a direct impact on the disposable income and savings of migrant workers and, consequently, on their capacity to remit. If remittances were strongly correlated with the host country's business cycle, it would be expected that remittances would decrease if a recession occurred in the host economy. Remittances would therefore be an additional channel through which cyclical fluctuations in the host economy could have an impact on the emigrant's home country. Moreover, the business cycles in the home and host countries may undergo direct and synchronous co-movement, which would inhibit the increase of remittances to aid family members during an economic recession in the home country, since the host country would also be facing an economic downturn.

Vargas-Silva (2008) examined the cyclical behaviour of workers' remittance flows to Mexico, finding them countercyclical with respect to the Mexican business cycle and not responsive to cyclical fluctuations in US output (the main host economy), although not robust to different definitions of remittances. For a panel data set of bilateral remittances from 103 Italian provinces to 107 developing countries, Bettin, Presbitero, and Spatafora (2014) found that remittances were negatively correlated with the business cycle in the recipient country and positively correlated with economic conditions in the sending province, suggesting remittances are countercyclical with respect to the recipient country when equivalent negative economic shocks affect both the host and the recipient economies. Sayan and Tekin-Koru (2012) investigated whether remittances sent to Turkey by Turkish workers living in Germany were countercyclical or procyclical with Turkish and German national outputs. They find remittances procyclical with respect to the business cycle of the home country (Turkey), and thus not smoothing macroeconomic fluctuations or reducing poverty in Turkey. Abdih et al. (2012) presented evidence for highly procyclical behaviour of remittance flows in relation to the economic conditions of the sending countries, using panel data for remittance-receiving countries in the Middle East, North Africa and Central Asia, with shocks in the sending countries transmitted via remittances to the public finances of the receiving countries, which may create volatility of government revenues.

A new strand of literature explores the relationship between the smoothing hypothesis and the optimum currency area (OCA) theory. In line with this view, if remittances are effective in smoothing output shocks, they may be considered as an alternative channel through which the members or candidate members of a currency union can absorb their asymmetric shocks. Frankel (2011) believed that if remittances are countercyclical then they should join trade, labour mobility and transfers on the list of OCA criteria. The results from Balli and Rana (2015), using a data sample of 86 developing countries, support Frankel's statement, leading to the conclusion that remittances can provide an effective channel for absorbing asymmetric shocks for several countries that aim to be part of a currency union. On the contrary, the findings from the study of 
Correia and Martins (2016) for 13 Euro Area (EA) countries do not support Frankel's statement. For the whole sample, the hypothesis of the countercyclicality of remittances was rejected. The results indicate a macroeconomic stabilizing effect only in the case of Lithuania.

Another subject that has been receiving attention in the empirical literature is the comparison between remittances and other external flows, namely foreign direct investment (FDI), capital non-FDI flows and official development aid in the context of developing countries. Ratha (2003) provided the first noteworthy contribution in this field of research, highlighting the importance of the evolution of global remittances for developing countries when compared to other sources of external financing such as exports, private capital and official flows. Additionally, the author found remittances to be more stable than private capital flows, which often moved procyclically. Subsequently, the behaviour of remittances has been compared with other external capital inflows in several other studies (e.g. Lueth and Ruiz-Arranz 2007; Vargas-Silva 2008; Neagu and Schiff 2009).

\section{Some facts about the dynamics of Portuguese remittances}

Remittances are 'personal transfers', or current transfers in cash or in kind received by resident households from non-resident households. Personal transfers are therefore a subset of current transfers and include all current transfers that are sent by individuals to individuals. The data on international remittance inflows used in this paper come from the Central Portuguese Bank, Balance of Payments Statistics. ${ }^{2}$ The statistics only include data on official international remittance flows (i.e. monetary remittances transmitted through official banking channels). They do not cover remittances transmitted through private or unrecorded channels. These private transfers include remittances brought home by friends or relatives or even by the migrants themselves (Adams 2009). As a result, the level of international remittances presented may underestimate the actual flow of remittances (official and unofficial) received in Portugal.

Through the analysis of the evolution of remittance receipts between 1996 and 2015 (Figure 1), it is possible to identify three sub-periods with markedly different evolutions. In the 1996-2001 period, there are high levels of remittances and the amount of remittances grows strongly (by about $37 \%$ in nominal value); the remittances reach their maximum in 2001 (at more than EUR 3.7 billion, which is $2.8 \%$ of GDP). The remittances then show oscillating behaviour in the period from 2002 to 2009 . There is a tendency to decrease between 2002 and 2005 (a fall of 19\%, and negative growth of 7\% per year), then steady growth until 2007 (of about 6.5\% each year), followed by a new period of decrease until 2009 (when remittances drop to EUR 2.3 billion and a historical low of $1.3 \%$ of GDP). Finally, the remittances present a new phase of growth in the period from 2010 to 2015, and this is particularly intense in 2012 (13\%) and 2013 (11\%). After 2013, remittances surpass 3 billion euros (for the first time since 2001) and represent about $1.8 \%$ of GDP (and $2.8 \%$ of private consumption and $4.1 \%$ of remuneration). In 2015 , Portugal received EUR 3.3 billion in remittances, the highest value since the creation of the euro, with a growth of $8 \%$, compared to an increase of $1 \%$ in 2014 . 


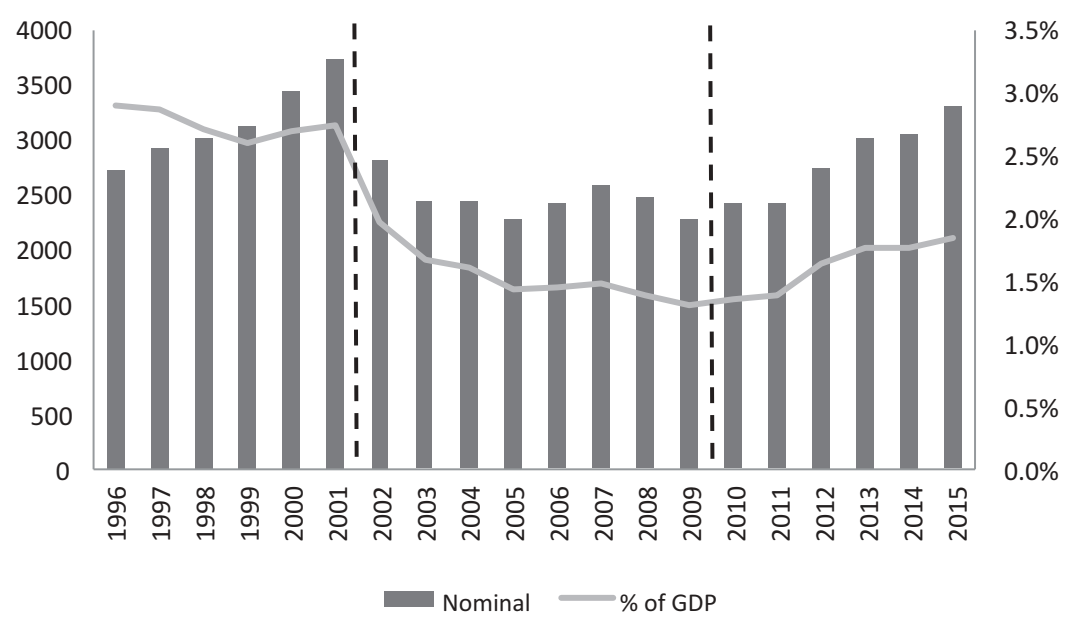

Figure 1. Remittances received in Portugal, 1996-2015, millions of euros.

Source of data: Bank of Portugal.

According to the World Bank Group (2016), in 2014 Portugal occupied sixth place on the list of countries in the group of high income OECD countries receiving migrant remittances. More than $80 \%$ of the remittances come from Europe, and most of them (about 60\%) originate from France and Switzerland, the two main host countries for Portuguese emigrants (Table Al in the Appendix).

The new phase of growth of inward remittances between 2010 and 2015 is related to the intensification of emigration following the global crisis which began with the US subprime mortgage crisis in 2007 and quickly spread to the world economy. Most of the European countries were strongly affected, experiencing severe economic downturn from 2008 onward. In some economies that were over-indebted, the repercussions of the Great Recession were amplified because the increase of the long-term interest rates on government bonds prevented them borrowing through the financial markets. Greece, Ireland, Portugal, and Cyprus received bailouts from the EU and IMF, but had to impose austerity programs. According to OECD (2015), Portugal assumed a larger package of fiscal consolidation, over $10 \%$ of GDP, to be implemented during the EFAP (May 2011-May 2014) to obtain the funding of $€ 78$ billion. The combination of this range of factors had extensive negative economic and social consequences for the Portuguese economy.

From Table 1, it is evident that permanent emigration ${ }^{3}$ rose faster after 2010, almost doubling in 2011, and continuing to grow until 2014. Considering total emigration (temporary and permanent), more than 586,000 people left Portugal between 2010 and $2015,485,000$ of them during the austerity programme, and many of these emigrants were young and highly qualified. In 2015, there was a slowing in the outflow of people from Portugal $(-25 \%)$, but it has remained above 100,000 people per year, a number that had only been seen previously in the 1960s and 1970s (Pires et al. 2016). This emigration was caused by the deterioration in economic and labour market conditions. During the four years of the EFAP, the labour force fell by nearly 203,000 people. About 309,000 jobs were destroyed, and unemployed grew from 688,000 in 2011 to 726,000 in 
Table 1. Emigration, labour force, employment and unemployment, 2009-2015.

\begin{tabular}{cccccccc}
\hline & \multicolumn{3}{c}{ Emigration (individuals) } & & & & \\
Year & Permanent & Temporary & Total & $\begin{array}{c}\text { Labour force } \\
\text { (thousands) }\end{array}$ & $\begin{array}{c}\text { Employment } \\
\text { (thousands) }\end{array}$ & $\begin{array}{c}\text { Unemployment } \\
\text { (thousands) }\end{array}$ & $\begin{array}{c}\text { Unemployment } \\
\text { rate (\%) }\end{array}$ \\
\hline 2009 & 16,899 & $\mathrm{x}$ & n.d. & $5,440.0$ & $4,877.7$ & 562.3 & 10.3 \\
2010 & 23,760 & $\mathrm{X}$ & n.d. & $5,451.2$ & $4,808.7$ & 642.5 & 11.8 \\
2011 & 43,998 & 56,980 & 100,978 & $5,428.3$ & $4,740.1$ & 688.2 & 12.7 \\
2012 & 51,958 & 69,460 & 121,418 & $5,382.6$ & $4,546.9$ & 835.8 & 15.5 \\
2013 & 53,786 & 74,322 & 128,108 & $5,284.6$ & $4,429.4$ & 855.3 & 16.2 \\
2014 & 49,572 & 85,052 & 134,624 & $5,225.6$ & $4,499.6$ & 726.1 & 13.9 \\
2015 & 40,377 & 60,826 & 101,203 & $5,195.2$ & $4,548.7$ & 646.5 & 12.4 \\
\hline
\end{tabular}

Sources of data: Bank of Portugal and National Statistics Office.

2014, with particular intensity in the years leading up to 2013, when the unemployment rate reached a historical peak of $16.2 \%$ (Table 1 ).

The economic situation deteriorated with the implementation of the fiscal consolidation policies negotiated with the Troika that were aimed at reducing the public deficit and the external debt. Because of this, the role of remittances as a source of external financing is interesting. Portugal is a net recipient country, and thus remittances offset Portuguese borrowing. In this study, we also analyse other two items of the balance of payments that play a similar role: receipts from tourism and travel, and capital transfers, which are also important external flows into the Portuguese economy. Figure 2 presents the evolution of these sources of foreign financing from 1996 to 2015.

In mean values, remittance inflows account for 1.9 per cent of Portugal's GDP. In some periods, remittance receipts exceeded capital transfers. This was the case from the mid-1990s until the circulation of the euro, in the second half of 2000s and in the period 2013-2015. The mean weight of remittances (\% of GDP) is higher than that of capital transfers, but well below that of receipts from travel and tourism. However,

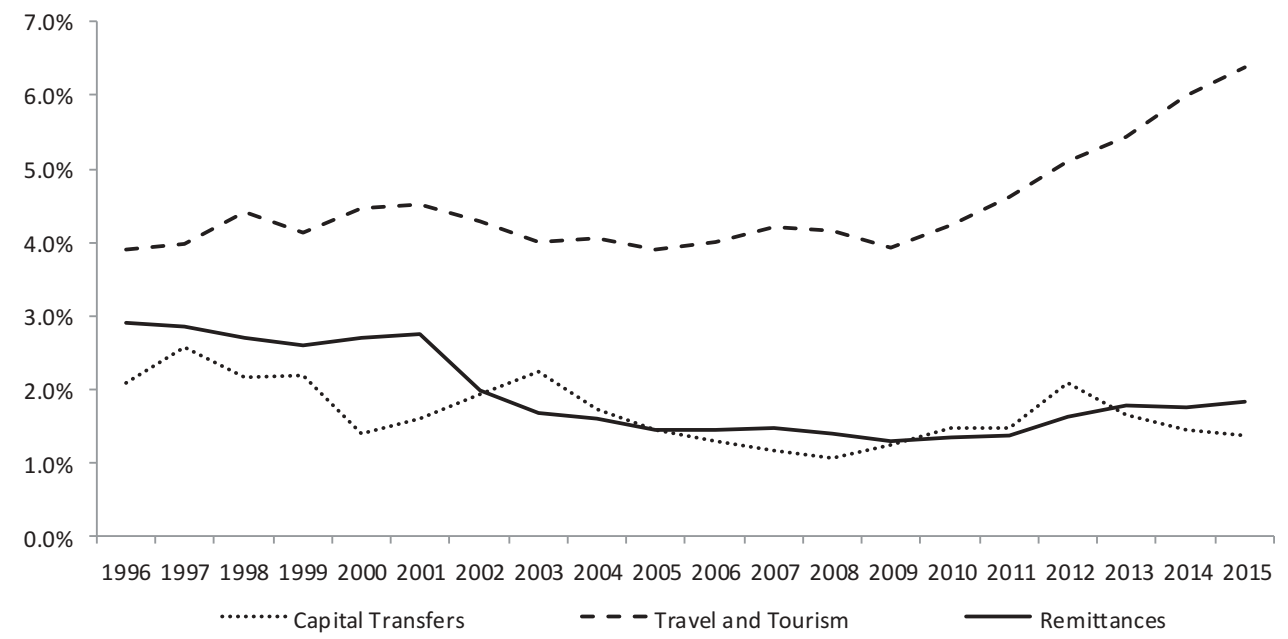

Figure 2. Some sources of foreign financing, 1996-2015, \% of GDP.

Source of data: Bank of Portugal. 
when compared with travel and tourism, remittances have a relatively low dispersion, which suggests that remittances are a relatively more stable capital source.

\section{Empirical analysis}

\subsection{Data and correlations}

Remittances and the other variables from the balance of payments (receipts from tourism and travel, and capital transfers) are available in the database of the Bank of Portugal (www.bportugal.pt) on a monthly basis, and were summed to obtain quarterly data. They are expressed in nominal terms and were converted from current into constant 2011 prices using the GDP deflator (2011:1). Quarterly data for the Portuguese GDP and its deflator were taken from Banco de Portugal (2016: 37), and quarterly data for the GDPs of France and Switzerland were obtained from the Eurostat database (http://ec.europa.eu/eurostat/data/database). All variables are expressed in real terms (2011 constant prices), in logarithmic form, in millions of euro, for the 1996q12015q4 period. We used the Baxter-King (BK) band-pass filter (Baxter and King 1999) to get the cyclical components of the remittances and GDP cycles, expressed in real terms. ${ }^{4}$ The filter was configured to extract cycles with periodicity between 6 and 32 quarters, corresponding to the duration of a typical business cycle.

The results (Figure 3) show the amplitude of the cycles of migration remittances was greater than that of the Portuguese business cycle. However, it is not possible to draw a clear conclusion about the sign or the degree of cyclical association between the two variables.

A visual inspection of the graphs of the cyclical components of remittances and the GDP of the main host remitting countries (Figure 4) also reveals that the cycle of remittances show greater fluctuations than the GDP cycles of France or Switzerland,

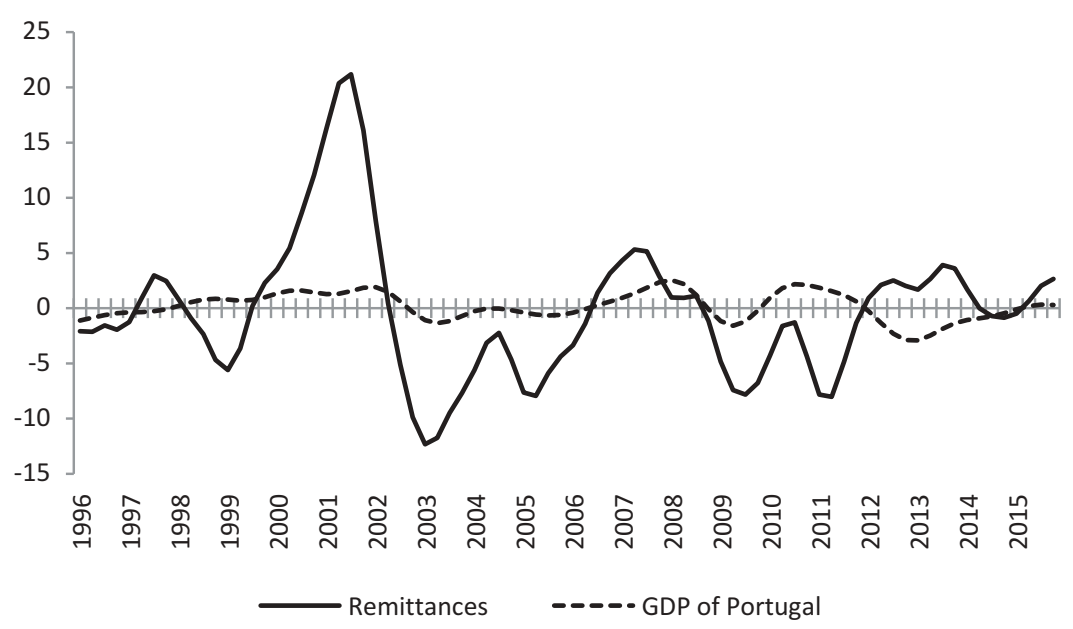

Figure 3. Cycle of remittances and GDP cycle for Portugal, 1996-2015.

Source of data: Bank of Portugal. 

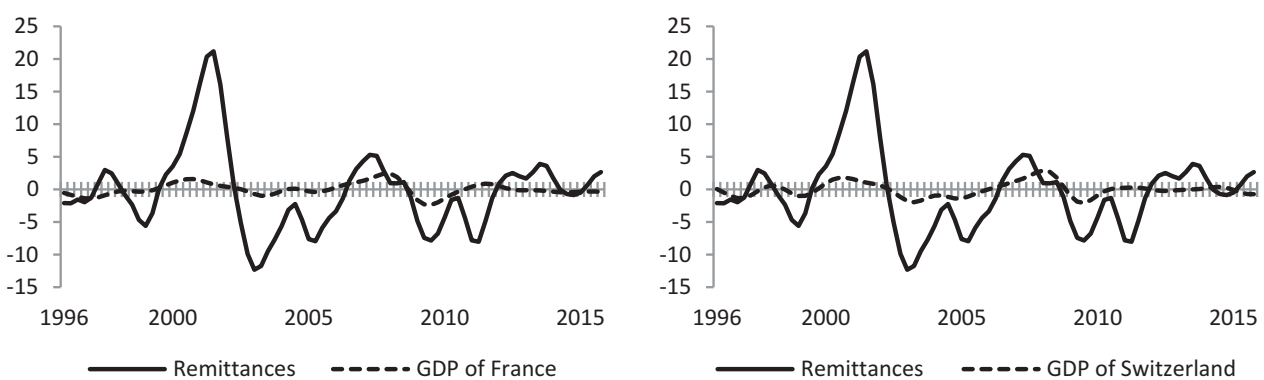

Figure 4. Cycle of remittances and GDP cycles for France and Switzerland, 1996-2015.

Sources of data: Bank of Portugal and Eurostat.

which exhibit smoother fluctuations over 1996-2015. Thus, a strong association between the cycles for the two variables is not perceptible.

After filtering the series, we calculated the bilateral Spearman correlation coefficients between the cycle of remittances and the business cycles of Portugal, France and Switzerland, to evaluate the degree of association. We considered the coefficients of contemporary correlation as well the maximum correlation or, in other words, the correlations with the cycle of remittances series shifted backwards and forwards. Following Perez, Osborn, and Sensier (2007), we considered a window encompassing five quarters of leads and lags and, from among these 11 correlations, we chose the highest figure (maximum correlation). Hence, we defined corr $\left(\mathrm{rem}_{t-\mathrm{i}}, \mathrm{c}_{t}\right)$ as the correlation between the cycle of remittances $\operatorname{rem}_{t-\mathrm{i}}$, with $-5 \leq i \leq 5$, and the business cycle $\mathrm{c}_{t}$. If the maximum correlation is obtained for $i=0$, the cycles are contemporaneously correlated; a positive (negative) value for $i$ means that the cycle of remittances leads (lags) the business cycle of the country under consideration by $i$ quarters.

We analysed the whole period (1996-2015) and, to perform a more detailed analysis, we computed the statistics for several sub-periods related to notable historical events that could have influenced the relationship between the remittance cycle and the GDP cycles of the home and host countries: before (1996-2001) and after (2002-2015) the circulation of the euro; and before (1996-2009) and after (2010-2015) the sovereign debt crisis. All these bilateral correlations between the cyclical components are displayed in Table 2.

Table 2. Correlation of remittance cycle with GDP cycles, whole period and sub-periods.

\begin{tabular}{|c|c|c|c|c|c|c|}
\hline & & Whole period & Before euro & After euro & Before crisis & After crisis \\
\hline GDP cycle of & Measures of correlation & 1996-2015 & 1996-2001 & 2002-2015 & 1996-2009 & 2010-2015 \\
\hline \multirow[t]{3}{*}{ Portugal } & Contemporaneous & $0.30^{* * * *}$ & $0.63^{* * *}$ & 0.15 & $0.77^{* * *}$ & $-0.79 * * *$ \\
\hline & Maximum & $0.32^{* * *}$ & $0.64^{* * *}$ & $-0.30^{* *}$ & $0.79 * * *$ & $-0.81^{* * *}$ \\
\hline & Lead/lag & 1 & 1 & -4 & 1 & 1 \\
\hline \multirow[t]{3}{*}{ France } & Contemporaneous & $0.54^{* * *}$ & $0.63^{* * *}$ & $0.49^{* * *}$ & $0.70^{* * *}$ & -0.07 \\
\hline & Maximum & $0.54^{* * *}$ & $0.67^{* * *}$ & $0.49^{* * *}$ & $0.70^{* * *}$ & $0.58^{* * *}$ \\
\hline & Lead/lag & 0 & -1 & 0 & 0 & -5 \\
\hline \multirow[t]{3}{*}{ Switzerland } & Contemporaneous & $0.71^{* * *}$ & $0.79^{* * *}$ & $0.64^{* * *}$ & $0.85^{* * *}$ & $-0.42^{* *}$ \\
\hline & Maximum & $0.73^{* * *}$ & $0.86^{* * *}$ & $0.64^{* * *}$ & $0.85^{* * *}$ & $-0.49^{* *}$ \\
\hline & Lead/lag & 1 & 1 & 0 & 0 & -1 \\
\hline
\end{tabular}

Statistical significance: * $10 \%$ level, ${ }^{* *} 5 \%$ level and ${ }^{* * *} 1 \%$ level.

Sources of data: Bank of Portugal and Eurostat. 
For the whole period, we found that remittances are positively and significantly associated with the GDP cycles of Portugal, France and Switzerland. The strongest correlation was found for Switzerland (0.7), followed by a moderate relationship for France (0.5) and a moderate association with the Portuguese business cycle (0.3). Additionally, these correlations achieved their maximum value in the current quarter, denoting contemporaneous procyclical behaviour of remittances.

The analysis by sub-periods reveals some significant changes in the degree and sign of the correlation coefficients. The comparison between the periods before and after the circulation of the euro shows that remittances remained procyclical relative to the French and Swiss business cycles, but with a lower degree of association. The alteration was greater in relation to the Portuguese GDP cycle: after the circulation of euro, remittances became countercyclical, with a weak $(-0.3)$ degree of association with the Portuguese business cycle, characterized by a lag of one year. The alterations are more noticeable when we compare the periods before and after the beginning of the sovereign debt crisis. The results show a clear change from procyclical to countercyclical behaviour for the remittances, relative to Portugal's output, with remittances displaying a strong, negative and statistically significant correlation $(-0.8)$ with the business cycle of Portugal after the crisis, which does not seem to be very sensitive to the use of leads or lags. The alteration is similar for the Swiss business cycle, although to a lesser extent, with remittances presenting strong procyclicality before $(0.9)$ and, inversely, moderate countercyclicality after $(-0.5)$, the sovereign debt crisis, with a tendency for remittances to be a lagging variable (a lag of one quarter). The degree of association with the French business cycle decreased after the crisis (from 0.7 to 0.6 ), but remittances remained procyclical although with some delay: there is no statistically significant correlation with French GDP in the current quarter, but the correlation is significant only in the fifth subsequent quarter (a lag of five quarters).

Overall, these results support the hypothesis that the sovereign debt crisis changed the cyclicality of Portuguese remittances.

\subsection{Econometric model and results}

While correlations are informative, they are simple bivariate statistics, and do not provide information about causality among the variables. To address these limitations, and guided by the theory, we estimated the baseline model [Equation (1)] to examine the relationship between the remittances cycle $\left(\operatorname{Rem}_{t}\right)$ and business cycles of Portugal $\left(\mathrm{GDPPTt}_{t}\right)$ the home country, and of France and Switzerland GDPFR $_{t}$ and $\mathrm{GDPCH}_{t}$ ), the main host countries for Portuguese emigrants.

$$
\operatorname{Rem}_{t}=\beta_{1}+\beta_{2} \mathrm{GDPPT}_{t}+\beta_{3} \mathrm{GDPFR}_{t}+\beta_{4} \mathrm{GDPCH}_{t}+\mu_{t}
$$

The estimated coefficients of the baseline model are displayed in column 1 of Table 3 . The coefficient of the GDP cycle of Switzerland is the only one that is statistically significant. ${ }^{5}$ Its positive sign means that Portuguese remittances showed a procyclical behaviour in relation to the Swiss GDP, probably because the economic conditions in this country affected the capacity of emigrants to remit. ${ }^{6}$

Given that different types of crises occurred after 2008 and they affected the economies of Portugal, France and Switzerland at different times and with different levels of intensity, we were not sure whether and when the relationship between the 
Table 3. Cyclicality of remittances: baseline and two sub-periods models.

\begin{tabular}{|c|c|c|c|c|}
\hline \multirow[b]{3}{*}{ Variables } & \multirow[b]{2}{*}{ Baseline model } & \multirow{2}{*}{$\frac{\text { Two sub-periods model }}{\text { GDP }}$} & \multicolumn{2}{|c|}{ Robustness check } \\
\hline & & & Consumption & Unemployment rate \\
\hline & (1) & (2) & (3) & (4) \\
\hline GDPPT & $-0.416(0.420)$ & & & \\
\hline GDPFR & $-0.878(0.700)$ & & & \\
\hline GDPCH & $4.741 * * *(0.819)$ & & & \\
\hline GDPPTbef & & $1.631 *(0.831)$ & & \\
\hline GDPPTaft & & $-1.423^{* * *}(0.281)$ & & \\
\hline CONSPTbef & & & $-0.017(0.073)$ & \\
\hline CONSPTaft & & & $-0.181^{* * *}(0.037)$ & \\
\hline UNEMPTbef & & & & $-2.241(1.789)$ \\
\hline UNEMPTaft & & & & $1.247^{* * *}(0.286)$ \\
\hline GDPFRbef & & $-1.321^{*}(0.789)$ & $-0.915(0.754)$ & $-0.778(0.766)$ \\
\hline GDPFRaft & & $-1.687^{*}(0.946)$ & $-4.137^{* * *}(0.819)$ & $-3.671^{* * *}(1.067)$ \\
\hline GDPCHbef & & $3.916^{* * *}(0.802)$ & $4.745^{* * *}(0.927)$ & $3.973^{* * *}(0.706)$ \\
\hline GDPCHaft & & $-4.041 * * *(0.511)$ & $-3.748^{* * *}(0.487)$ & $-4.660^{* * *}(0.719)$ \\
\hline Constant & $-0.001(0.005)$ & $-0.008^{*}(0.004)$ & $-0.003(0.006)$ & $-0.005(0.004)$ \\
\hline Observations & 80 & 80 & 80 & 80 \\
\hline$R^{2}$ & 0.45 & & 0.54 & 0.55 \\
\hline $\begin{array}{l}\text { Supremum Wald test } \\
\text { (p-value) }\end{array}$ & $189.396(0.000)$ & & & \\
\hline
\end{tabular}

Statistical significance: * $10 \%$ level, $* * 5 \%$ level and $* * * 1 \%$ level.

Robust standard errors are in parentheses.

Sources of data: Bank of Portugal and Eurostat.

remittances and the GDPs of those economies underwent structural shifts. Because of that, we performed a supremum Wald test (Table 3) to verify the existence of a structural break at an unknown break date. The results reject the null hypothesis of no structural break and indicate that the estimated break date is $2010 \mathrm{q} 4$. As we are investigating whether the sovereign debt crisis changed the cyclicality of Portuguese remittances, we define a two sub-periods model [Equation (2)] in which the remittances cycle is explained by the GDP cycles of Portugal, France and Switzerland in the periods 1996q1-2010q3 (GDPPTbef , GDPFRbef $_{t}$ and GDPCHbef ${ }_{t}$ ) and 2010q4-2015q4 $\left(\right.$ GDPPTaft $_{t}$, GDPFRaft $_{t}$ and GDPCHaft ${ }_{t}$ ), which correspond to the periods before and after the beginning of the sovereign debt crisis in Portugal, respectively.

$$
\begin{aligned}
\text { Rem }_{t}= & \beta_{1}+\beta_{2} \text { GDPPTbef }_{t}+\beta_{3} \text { GDPPTaft }_{t}+\beta_{4} \text { GDPFRbef }_{t}+\beta_{5} \text { GDPFRaft }_{t} \\
& +\beta_{6} \text { GDPCHbef }_{t}+\beta_{7} \text { GDPCHaft }_{t}+\mu_{t}
\end{aligned}
$$

Specifically, we aimed to test two hypotheses:

H1: The relationship between the remittances cycle and the Portuguese business cycle was procyclical before the crisis and countercyclical in the crisis years. If $\beta_{2}$ is positive and $\beta_{3}$ is negative, the altruistic motive to remit only prevailed during the sovereign debt crisis, and the remittances contributed to the stabilization of the Portuguese economy in that period;

H2: The relationship between the remittances and the GDP of the two main host countries was procyclical before and after the sovereign debt crisis. If the coefficients $\beta_{4}$ to $\beta_{7}$ are positive, this means that when the GDPs of France and Switzerland decreased 
(increased), the remittances also decreased (increased), which confirms that the economic conditions in the host countries affected the capacity of migrants to remit.

The estimated coefficients of the two sub-periods model are displayed in column 2 of Table 3. To check the robustness of our results, we also estimated Equation (2) using two different data sets instead of the GDP cycle to represent the cyclical position of the Portuguese economy: the cycle of private consumption and the cycle of the unemployment rate (column 3 and column 4 of Table 3$).^{7}$

The econometric results confirm that, after the last quarter of 2010, remittances were countercyclical in relation to the Portuguese business cycle. This statement remains true whichever data set is used to represent that cyclical position. A decrease in GDP, a decrease in private consumption or an increase in the unemployment rate implies an increase in remittances received by Portuguese households, contributing to the stabilization of the Portuguese economy in that period. With respect to the relationship between the remittances cycle and the Portuguese business cycle in the years before the crisis, the results are sensitive to the data set used, and suggest a procyclical relation when GDP is used.

The estimated coefficients of the GDP cycles of Switzerland are both significant and their interpretation means that the Portuguese remittances showed procyclical behaviour in relation to the Swiss GDP before the crisis, being countercyclical after the crisis. Thus, the relationship between the remittances cycle and the GDP cycles of Portugal and Switzerland is similar in the two sub-periods. The results also indicate that the Portuguese remittances were countercyclical with respect to the GDP cycle of France, but this conclusion is not robust to the use of different data sets in the period before the crisis.

We also regressed two additional estimations with the interaction variables (Table A2 in the Appendix). In the first additional estimation, our purpose was to test whether the sign and significance of the estimated coefficients for Portuguese GDP before and after the crisis changed according to whether the economic situation in Portugal was positive or negative. In this estimation, we used explanatory variables such as GDPPTbef ${ }^{\star}$ positivePT that allowed us to investigate the relationship between the cycles for remittances and Portuguese GDP before the crisis when the GDP cycle of Portugal was positive. In a different way, in the second estimation with interaction variables, we examined whether the relationship between the remittances cycle and the Portuguese GDP cycle depends on the business cycle of the host countries. We considered, for example, the explanatory variable GDPPTbef*positiveFRCH to verify whether, before the sovereign debt crisis, the relationship between the remittances cycle and the Portuguese GDP cycle depended on the sign of the cycle of the sum of the French and Swiss GDPs.

The results confirm that deteriorations in the Portuguese GDP were accompanied by improvements in remittances during the sovereign debt crisis period (2010q4-2015q4), regardless of the cyclical position of the economies considered. In the years before that crisis (1996q1-2010q3), the remittances were procyclical with respect to the Portuguese output when the economy of Portugal was below the trend and when the two main host economies were above the trend. In these regressions, the conclusion that Portuguese remittances were procyclical before the crisis and countercyclical after the crisis in 
relation to the Swiss GDP remains true. However, with respect to the GDP cycle of France, the results indicate that the Portuguese remittances were countercyclical only in the period before the crisis.

In the literature, the cyclicality of remittances has been compared with the cycles of alternative sources of external financing. In this study, we considered two items of the Portuguese balance of payments that show a surplus over the sample period: 1) travel and tourism receipts and 2) capital transfers. These, in addition to remittances, are important external flows into Portugal's economy. In this analysis, we used the following model:

Item_BP $_{t}=\beta_{1}+\beta_{2}$ GDPPTbef $_{t}+\beta_{3}$ GDPPTaft $_{t}+\beta_{4}$ GDPEAbef $_{t}+\beta_{5}$ GDPEAaft $_{t}+\mu_{t}$

The dependent variable Item_BP $P_{t}$ is the cycle of one of the three items of the balance of payments in the analysis: remittances, receipts from travel and tourism and capital transfers. In this model, the explanatory variables are the Portuguese GDP cycle before $\left(\right.$ GDPPTbef $_{t}$ ) and after (GDPPTaft ${ }_{t}$ ) the beginning of the sovereign debt crisis, as in the previous model, and the EA GDP cycle for the same two sub-periods (GDPEAbef $_{t}$ and GDPEAaft ${ }_{t}$, respectively). ${ }^{8}$

Since it is not appropriate to apply the terminology of 'host country' in the case of travel and tourism receipts and capital transfers, we chose the EA as the main counterpart source for these inflows. This choice allows us to investigate their potential synchronization role between Portuguese GDP and the economy of the EA. If one item is procyclical with respect to the output of the EA, it can act as a mechanism of synchronization. Thus, it can, for example, improve the timing of the European Central Bank's decisions with respect to Portugal, which is an important contribution for small economies such as Portugal's that do not affect those monetary policy decisions. Thus, this model [Equation (3)] aims to investigate two hypotheses:

H1: The relationship between the cycles for receipts from travel and tourism and capital transfers and the Portuguese GDP cycle is similar to the relationship between the remittances cycle and the Portuguese business cycle. If $\beta_{2}$ and $\beta_{3}$ in Equation (3) have the same sign as they do in the two sub-periods model [Equation (2)], the three balance of payments items considered affect the Portuguese GDP in the same way;

H2: The relationship between the cycle for each of the balance of payments items considered and the GDP cycle for the EA is procyclical. If $\beta_{4}$ and $\beta_{5}$ are positive, this means that when the GDP of the EA decreases (increases), the inflows from the item under consideration also decrease (increases), and thus those inflows act as a mechanism of synchronization between the business cycles of the EA and Portugal.

Table 4 presents the results from the estimation of Equation (3). The estimated coefficients confirm that the relationship between remittances and the Portuguese GDP was procyclical before the last quarter of 2010 and countercyclical after that period. The cycle for travel and tourism inflows is also procyclical with respect to the GDP cycle of Portugal before the crisis, but unlike remittances those inflows did not stabilized the 
Table 4. Cyclicality of remittances, travel and tourism receipts and capital transfers.

\begin{tabular}{|c|c|c|c|}
\hline & Remittances & Travel and Tourism Receipts & Capital Transfers \\
\hline Variables & (1) & (2) & (3) \\
\hline GDPPTbef & $2.186 * * *(0.720)$ & $1.695 * * *(0.586)$ & $-7.537 * *(3.063)$ \\
\hline GDPPTaft & $-1.459 * * *(0.457)$ & $-0.111(0.526)$ & $-8.210 * *(3.224)$ \\
\hline GDPEAbef & $2.348 * * *(0.784)$ & $1.794 * * *(0.492)$ & $0.307(2.324)$ \\
\hline GDPEAaft & $-0.872(0.839)$ & $0.705(1.082)$ & $13.907^{* * *}(4.789)$ \\
\hline Constant & $-0.013 * *(0.005)$ & $-0.007^{* * *}(0.003)$ & $0.021(0.016)$ \\
\hline Observations & 80 & 80 & 80 \\
\hline $\mathrm{R}^{2}$ & 0.51 & 0.65 & 0.24 \\
\hline
\end{tabular}

Statistical significance: ${ }^{*} 10 \%$ level, ${ }^{* *} 5 \%$ level and ${ }^{* * *} 1 \%$ level.

Robust standard errors are in parentheses.

Sources of data: Bank of Portugal and Eurostat.

Portuguese economy in the crisis period. In contrast, capital transfers behaved countercyclically both before and after the sovereign debt crisis, and the estimated coefficients for these inflows are the highest of those for the three items, giving it an important role as an instrument of economic stabilization.

Regarding the cyclicality of the three items of the balance of payments with respect to the cycle of the GDP of the EA, the results suggest a procyclical or acyclical relationship. With respect to the cycle for remittances and for travel and tourism receipts, the estimated coefficients are only significant before the crisis. Capital transfers, in its turn, were a mechanism of synchronization between the GDP of Portugal and EA only in the crisis years.

\section{Conclusions}

In this paper, we have analysed the cyclical pattern of remittances of Portuguese emigrants relative to the business cycles of Portugal and of the two main host countries (France and Switzerland), and the potentially important role of remittances in providing insurance against domestic shocks. We also investigated whether the sovereign debt crisis and the austerity measures which followed changed the cyclicality of Portuguese remittances. This research uses quarterly data for 1996-2015 and applies two approaches, namely bilateral correlations and econometric model regression.

Our main finding is that remittances were countercyclical in relation to Portuguese GDP in the sovereign debt crisis period (2010q4-2015q4). This conclusion is valid regardless of the economic situation of the home and host countries, and is robust to the use of different statistical information to measure the Portuguese business cycle (GDP, private consumption or unemployment rate). Thus, this result supports the smoothing hypothesis for this period, suggesting that remittances received by Portuguese households played a role in stabilizing the economy. That role was even more important because, under the Troika's programme, Portugal's fiscal policy was managed to reduce the budget deficit and public debt, thus contributing to the deepening of the economic recession.

In fact, our findings indicate that the sovereign debt crisis changed the cyclicality of remittances, which were procyclical or acyclical in the years before that crisis. In the period 1996q1-2010q3, remittance inflows accompanied the Portuguese business cycle 
when the Portuguese economy was in an economic downturn and when the cycle of the sum of the French and Swiss GDPs was positive.

With respect to the relationship between the remittances cycle and the main host countries business cycles, the main conclusion is that the remittances appear to have been procyclical in relation to the Swiss GDP before the crisis and countercyclical in the crisis years. Regarding the French business cycle, in the years before the crisis the results are sensitive to the data set used to measure the business cycle of Portugal (GDP, private consumption or unemployment rate) and in crisis period the estimated coefficients suggest an acyclical or countercyclical relation.

A comparison of the cyclicality of the remittances, travel and tourism inflows and capital transfers in relation to the Portuguese business cycle allows us to verify that the capital transfers were the only item with a countercyclical relation with Portuguese GDP before the crisis years. However, in the crisis years, the remittances may also have been a stabilizing instrument unlike the travel and tourism inflows which present an acyclical relation with GDP of Portugal in that period.

As regards the hypothesis of synchronization between the business cycles of Portugal and the EA, the remittances and the travel and tourism inflows may have had that role before the crisis years, since they were procyclical in relation to the EA GDP cycle. The capital transfers could have been, in its turn, a mechanism of synchronization in the crisis years.

Our findings show that the remittances were important to stabilize the Portuguese economy after the beginning of the sovereign debt crisis and may have been a mechanism of synchronization with respect to the EA GDP before the crisis.

\section{Notes}

1. According to the World Bank, the true total amount of remittances, including unrecorded flows through formal and informal channels, is significantly larger.

2. http://www.bportugal.pt/EstatisticasWeb/(S(30hwbcv5zcrqjm45r1tbcyr4))/ SeriesCronologicas.aspx. Monthly data are available, and these were summed to obtain the quarterly and annual data. The remittance inflows are accounted for in the current account, secondary income account, under the heading of 'remittances of immigrants/ emigrants'.

3. In 2009 and 2010 there is information available concerning only permanent emigration.

4. The literature suggests several techniques for filtering, of which the BK filter is one of the most popular, being appropriate from a theoretical point of view (Stock and Watson 1998). See Canova (2007) for a useful survey and discussion about the decomposition of a series into cyclical and trend components.

5. The correlation between the estimated coefficients of the GDP cycles of France and Switzerland is high (-0.7). As the variance inflation factor (VIF) for these variables don't exceed the rule of thumb of 10 , we considered that multicollinearity is not a concern.

6. We investigated the effect of EMU membership on Portuguese remittance inflows using a dummy variable taking the value 1 in the years after 1999, but it was not statistically significant.

7. The original data for these variables come from Banco de Portugal [Bank of Portugal] (2016). Private consumption is expressed in millions of euros, at 2011 constant prices, and was put in logarithmic form before its cyclical component was extracted. In the case of the unemployment rate, it was not necessary to work with logarithms. 
8. The original quarterly data for the GDP of the EA are expressed in millions of euros, at 2010 constant prices, and are obtained from the Eurostat database (http://ec.europa.eu/ eurostat/data/database). We converted the series into 2011 constant prices and took the logarithmic form to estimate the EA's business cycle.

\section{Acknowledgments}

The authors are grateful to the anonymous referees of this journal for their helpful comments. The usual disclaimer applies.

\section{Disclosure statement}

No potential conflict of interest was reported by the authors.

\section{Funding}

This work was supported by national funds provided by the Portuguese Foundation for Science and Technology (FCT) [project number UID/SOC/04011/2013].

\section{ORCID}

Leonida Correia (D) http://orcid.org/0000-0002-2762-6965

Patrícia Martins (D) http://orcid.org/0000-0002-4493-963X

\section{References}

Abdih, Y., A. Barajas, R. Chami, and C. Ebeke. 2012. "Remittances Channel and Fiscal Impact in the Middle East, North Africa, and Central Asia." IMF Working Paper 12/104. Washington: International Monetary Fund. doi:10.5089/9781475502947.001

Acosta, P., C. Calderón, P. Fajnzylber, and H. Humberto. 2008. "What Is the Impact of International Remittances on Poverty and Inequality in Latin America?" World Development 36 (1): 89-114. doi:10.1016/j.worlddev.2007.02.016.

Acosta, P., E. K. K. Lartey, and F. S. Mandelman. 2009. "Remittances and the Dutch Disease." Journal of International Economics 79: 102-116. doi:10.1016/j.jinteco.2009.06.007.

Adams, R. H., Jr. 2009. "The Determinants of International Remittances in Developing Countries." World Development 37 (1): 93-103. doi:10.1016/j.worlddev.2007.11.007.

Artal-Tur, A., J. Bacaria-Colom, S. Çagatay, and V. Pallardó-López. 2014. “The Determinants of Migrants' Remittance Inflows in the MENA Region: A Macroeconomic Approach.” In The Socio-Economic Impact of Migration Flows: Effects on Trade, Remittances, Output, and the Labour Market, edited by A. Artal-Tur, G. Peri, and F. Requena-Silvente, 97-120. New York: Springer.

Balli, F., and F. Rana. 2015. "Determinants of Risk Sharing Through Remittances." Journal of Banking \& Finance 55: 107-116. doi:10.1016/j.jbankfin.2015.02.003.

Banco de Portugal [Bank of Portugal]. 2016. "Economic Bulletin: June 2016”. Lisboa: Banco de Portugal. https://www.bportugal.pt/sites/default/files/anexos/pdf-boletim/bol_econ_june16_e. pdf

Barajas, A., R. Chami, C. Fullenkamp, M. Gapen, and P. Montiel. 2009. "Do Workers' Remittances Promote Economic Growth?" IMF Working Paper 09/153. Washington: International Monetary Fund. 
Baxter, M., and R. King. 1999. "Measuring Business Cycles: Approximate Band-Pass Filters for Economic Time Series." The Review of Economics and Statistics 81: 575-593. doi:10.1162/ 003465399558454.

Bettin, G., A. F. Presbitero, and N. Spatafora. 2014. "Remittances and Vulnerability in Developing Countries." IMF Working Paper 14/13. Washington: International Monetary Fund. doi:10.5089/9781484385081.001.

Canova, F. 2007. Methods for Applied Macroeconomic Research. New Jersey: Princeton University Press.

Chami, R., C. Fullenkamp, and S. Jahjah. 2005. “Are Immigrant Remittance Flows a Source of Capital for Development?” IMF Staff Papers 52 (1): 55-81.

Chami, R., D. Hakura, and P. Montiel. 2009. "Remittances: An Automatic Output Stabilizer?" IMF Working Paper 08/29. Washington: International Monetary Fund.

Correia, L. 2016. "The European Crisis: Repercussions on the Portuguese Economy." Athens Journal of Mediterranean Studies 2 (2): 129-144.

Correia, L., and P. Martins. 2016. "Are Remittances an Instrument of Stabilization and Funding in the Euro Area?” Applied Economic Letters 23 (16): 1177-1181. doi:10.1080/ 13504851.2016.1142647.

Frankel, J. 2011. “Are Bilateral Remittances Countercyclical?” Open Economies Review 22: 1-16. doi:10.1007/s11079-010-9184-y.

Giuliano, P., and M. Ruiz-Arranz. 2009. "Remittances, Financial Development, and Growth.” Journal of Development Economics 90 (1): 144-152. doi:10.1016/j.jdeveco.2008.10.005.

Le, T. 2009. "Trade, Remittances, Institutions, and Economic Growth.” International Economic Journal 23 (3): 391-408. doi:10.1080/10168730903119443.

Lucas, R. E. B., and O. Stark. 1985. "Motivations to Remit: Evidence from Botswana." Journal of Political Economy 93 (5): 901-918. doi:10.1086/261341.

Lueth, E., and M. Ruiz-Arranz. 2006. “A Gravity Model of Workers' Remittances.” IMF Working Paper 06/290. Washington: International Monetary Fund. doi:10.5089/9781451865509.001.

Lueth, E., and M. Ruiz-Arranz. 2007. "Are Workers' Remittances a Hedge against Macroeconomic Shocks? The Case of Sri Lanka." Asia-Pacific Development Journal 14 (1): 25-39.

Neagu, I. C., and M. Schiff. 2009. "Remittance Stability, Cyclicality and Stabilizing Impact in Developing Countries.” The World Bank, Policy Research Working Paper 5077. Washington, DC: World Bank.

OECD. 2015. In It Together: Why Less Inequality Benefits All. Paris: OECD Publishing. doi:10.1787/9789264235120-en.

Perez, P., D. Osborn, and M. Sensier. 2007. "Business Cycle Affiliations in the Context of European Integration.” Applied Economics 39 (2): 199-214. doi:10.1080/ 00036840500427924.

Pires, R. P., C. Pereira, J. Azevedo, I. Espírito-Santo, and I. Vidigal. 2016. Portuguese Emigration Factbook 2015. Lisboa: Observatório da Emigração e Rede Migra, CIES-IUL, ISCTE-IUL. doi:10.15847/CIESOEMRE032016.

Ratha, D. 2003. "Workers' Remittances: An Important and Stable Source of External Development Finance." In Global Development Finance 2003 (Chapter 7). Washington: World Bank.

Sayan, S. 2006. "Business Cycles and Workers' Remittances: How Do Migrant Workers Respond to Cyclical Movements of GDP at Home?" IMF Working Paper 06/52. Washington: International Monetary Fund. doi:10.5089/9781451863123.001.

Sayan, S., and A. Tekin-Koru. 2012. "Remittances, Business Cycles and Poverty: The Recent Turkish Experience.” International Migration 50 (S1): e151-e176. doi:10.1111/imig.2012.50. issue-s1.

Senbeta, A. 2013. "Remittances and the Sources of Growth." Applied Economics Letters 20 (6): 572-580. doi:10.1080/13504851.2012.718057. 
Stock, J., and M. Watson. 1998. "Business Cycle Fluctuations in U. S. Macroeconomics Time Series.” National Bureau for Economic Research Working Paper 6528. Cambridge: National Bureau of Economic Research.

United Nations. 2015. Trends in International Migrant Stock: Migrants by Destination and Origin. Department of Economic and Social Affairs, Population Division (United Nations database, POP/DB/MIG/Stock/Rev.2015). New YorK: United Nations.

Vargas-Silva, C. 2008. "Are Remittances Manna from Heaven? A Look at the Business Cycle Properties of Remittances." The North American Journal of Economics and Finance 19 (3): 290-303. doi:10.1016/j.najef.2008.03.001.

World Bank. 2006. Global Economic Prospects: Economic Implications of Remittances and Migration. World Bank. Washington, DC: World Bank.

World Bank. 2014. Migration and Remittances: Recent Developments and Outlook. Migration and Development Brief: Migration and Remittances Team, Development Prospects Group. Washington, DC: World Bank.

World Bank Group. 2016. Migration and Remittances Factbook 2016. 3rd ed. World Bank. Washington, DC: World Bank.

Ziesemer, T. H. W. 2012. "Worker Remittances, Migration, Accumulation and Growth in Poor Developing Countries: Survey and Analysis of Direct and Indirect Effects." Economic Modelling 29 (2): 103-118. doi:10.1016/j.econmod.2011.08.013.

\section{Appendix}

Table A1. Origin of remittances received in Portugal, 1996-2015 (\% of total).

\begin{tabular}{rccccccccccccccc}
\hline & FR & CH & DE & UK & ES & LU & BE & NL & IT & Europe & AN & CN & US & OT & Total \\
\hline 1996 & 40.3 & 20.7 & 9.4 & 3.2 & 1.5 & 3.0 & 2.0 & 0.9 & 0.3 & 81.3 & 0.2 & 2.7 & 12.4 & 3.4 & 100.0 \\
1997 & 40.1 & 20.5 & 8.4 & 3.8 & 1.4 & 2.6 & 1.5 & 0.8 & 0.2 & 79.3 & 0.3 & 3.3 & 13.4 & 3.7 & 100.0 \\
1998 & 42.5 & 17.8 & 7.3 & 3.9 & 2.0 & 2.4 & 1.3 & 0.7 & 0.2 & 78.1 & 0.4 & 2.9 & 15.2 & 3.4 & 100.0 \\
1999 & 40.6 & 18.1 & 7.8 & 5.1 & 2.6 & 2.0 & 2.3 & 0.6 & 0.2 & 79.3 & 0.2 & 3.4 & 12.7 & 4.4 & 100.0 \\
2000 & 38.6 & 19.0 & 8.0 & 5.7 & 1.6 & 1.9 & 1.6 & 0.5 & 0.2 & 77.1 & 0.3 & 4.2 & 12.8 & 5.6 & 100.0 \\
2001 & 40.7 & 19.3 & 8.7 & 6.2 & 1.6 & 2.7 & 1.2 & 0.5 & 0.2 & 81.1 & 0.2 & 3.1 & 10.6 & 5.0 & 100.0 \\
2002 & 33.2 & 22.3 & 7.3 & 7.7 & 2.8 & 3.7 & 1.0 & 0.7 & 0.3 & 79.0 & 0.5 & 3.2 & 13.2 & 4.1 & 100.0 \\
2003 & 36.4 & 21.2 & 8.4 & 7.3 & 2.9 & 3.6 & 1.0 & 0.6 & 0.4 & 81.8 & 0.4 & 3.4 & 11.2 & 3.2 & 100.0 \\
2004 & 39.5 & 21.7 & 7.3 & 7.4 & 2.5 & 3.1 & 0.9 & 0.6 & 0.4 & 83.4 & 0.8 & 3.0 & 9.5 & 3.3 & 100.0 \\
2005 & 39.9 & 22.8 & 7.2 & 6.5 & 2.3 & 3.1 & 0.9 & 0.4 & 0.3 & 83.4 & 1.0 & 3.2 & 9.6 & 2.8 & 100.0 \\
2006 & 40.4 & 21.9 & 7.0 & 6.3 & 2.6 & 3.4 & 1.2 & 0.4 & 0.2 & 83.4 & 1.4 & 2.8 & 9.2 & 3.2 & 100.0 \\
2007 & 39.6 & 21.0 & 6.6 & 6.3 & 3.7 & 3.5 & 1.5 & 0.6 & 0.4 & 83.2 & 1.9 & 3.0 & 7.8 & 4.1 & 100.0 \\
2008 & 39.6 & 22.3 & 5.9 & 5.0 & 5.1 & 2.9 & 1.4 & 0.7 & 0.4 & 83.3 & 2.9 & 2.3 & 6.9 & 4.6 & 100.0 \\
2009 & 38.9 & 23.3 & 5.3 & 4.2 & 5.4 & 3.6 & 1.4 & 0.8 & 0.5 & 83.4 & 4.5 & 1.8 & 5.6 & 4.7 & 100.0 \\
2010 & 37.1 & 25.3 & 5.0 & 3.9 & 4.6 & 3.5 & 1.4 & 0.9 & 0.6 & 82.3 & 5.6 & 1.9 & 5.4 & 4.8 & 100.0 \\
2011 & 35.7 & 28.0 & 4.7 & 4.3 & 3.6 & 2.8 & 1.6 & 1.1 & 0.5 & 82.3 & 6.1 & 1.7 & 5.4 & 4.5 & 100.0 \\
2012 & 30.8 & 25.4 & 6.3 & 4.7 & 4.7 & 2.7 & 1.9 & 1.7 & 0.7 & 78.9 & 9.8 & 1.7 & 4.9 & 4.7 & 100.0 \\
2013 & 29.7 & 24.5 & 6.5 & 5.2 & 5.2 & 2.9 & 2.2 & 2.0 & 0.7 & 78.9 & 10.1 & 1.4 & 4.7 & 4.9 & 100.0 \\
2014 & 28.8 & 26.6 & 6.4 & 6.6 & 5.5 & 3.1 & 2.5 & 1.2 & 0.1 & 80.8 & 8.1 & 2.1 & 5.3 & 3.7 & 100.0 \\
2015 & 31.2 & 25.4 & 7.7 & 7.7 & 3.8 & 3.5 & 2.0 & 1.3 & 0.1 & 82.7 & 6.6 & 1.0 & 6.5 & 3.2 & 100.0 \\
Mean & $\mathbf{3 7 . 2}$ & $\mathbf{2 2 . 4}$ & $\mathbf{7 . 1}$ & $\mathbf{5 . 6}$ & $\mathbf{3 . 3}$ & $\mathbf{3 . 0}$ & $\mathbf{1 . 5}$ & $\mathbf{0 . 9}$ & $\mathbf{0 . 3}$ & $\mathbf{8 1 . 2}$ & $\mathbf{3 . 1}$ & $\mathbf{2 . 6}$ & $\mathbf{9 . 1}$ & $\mathbf{4 . 1}$ & $\mathbf{1 0 0 . 0}$ \\
\hline
\end{tabular}

FR - France; CH - Switzerland; DE - Germany; UK - United Kingdom; ES - Spain; LU - Luxembourg; BE - Belgium; NL Netherlands; IT - Italy; AN - Angola, CN - Canada; US - United States; OT - Others.

Source of data: Bank of Portugal. 
Table A2. Cyclicality of remittances: interaction variables.

\begin{tabular}{|c|c|c|}
\hline \multirow[b]{3}{*}{ Variables } & \multicolumn{2}{|c|}{ Interaction variables } \\
\hline & Portuguese GDP is positive or negative & GDP of host country is positive or negative \\
\hline & $(1)$ & (2) \\
\hline GDPPTbef*positive PT & $0.680(1.130)$ & \\
\hline GDPPTbef*negative PT & $3.491 * * *(1.158)$ & \\
\hline GDPPTbef* positive FRCH & & $2.874 *(1.521)$ \\
\hline GDPPTbef*negative FRCH & & $0.964(0.616)$ \\
\hline GDPPTaft ${ }^{*}$ positive PT & $-3.010 * * *(0.861)$ & \\
\hline GDPPTaft*negative PT & $-0.743 * *(0.364)$ & \\
\hline GDPPTaft* positive FRCH & & $-1.900 * * *(0.539)$ \\
\hline GDPPTaft ${ }^{*}$ negative FRCH & & $-1.450 * * *(0.337)$ \\
\hline GDPFRbef & $-1.558 *(0.807)$ & $-1.608 *(0.827)$ \\
\hline GDPFRaft & $-0.824(0.838)$ & $-1.342(1.060)$ \\
\hline GDPCHbef & $4.176^{* * *}(0.807)$ & $3.630 * * *(0.815)$ \\
\hline GDPCHaft & $-3.454 * * *(0.522)$ & $-3.761 * * *(0.833)$ \\
\hline Constant & $0.003(0.007)$ & $-0.013 * * *(0.005)$ \\
\hline Observations & 80 & 80 \\
\hline $\mathrm{R}^{2}$ & 0.57 & 0.57 \\
\hline
\end{tabular}

Statistical significance: * $10 \%$ level, ${ }^{* *} 5 \%$ level and ${ }^{* * *} 1 \%$ level. Note: Robust standard errors are given in parentheses.

Sources of data: Bank of Portugal and Eurostat. 